\title{
İnsan Üzerindeki Deneyler ve İlgili Etik- Yasal Metinler
}

\section{Human Experimentation and the Relevant Ethicolegal Texts}

\begin{abstract}
Özet
Insanlar üzerinde gerek geçmişte Nazi Almanyası'nda yapılan deneyler, gerekse sonraki yıllarda gerçekleştirilen Tuskegee sifilis ve Guatemala CYBH araştırmaları ve de günümüzde de sürmekte olan klinik farmasötik deneyler sonucunda, insan deneklerin uğrayabileceği zararlar ve sömürü uzun zamandır ciddi bir sorun olarak tartışılagelmiştir. Özellikle Nazi bilim adamlarınca insanlar üzerinde yapılan deneylere dair Nürnberg'de gerçekleştirilen yargılamalar sırasında bu çalışmaları düzenleyici, uluslararası geçerlilikte bir kod olmadığı fark edilmiş ve bu eksikliği gidermek için Nürnberg Kodu oluşturularak ülkelerce kabul edilmiştir. Günümüzde in vivo farmasötik deneyler, in vitro prosedürler, kök hücre çalışmaları vb. ile, insanlar ve de insan doku ve hücreleri üzerinde tarihte daha önce hiç olmadığı kadar çeşitli ve karmaşık bilimsel araştırmalar gerçekleştirilmektedir. Insan üzerindeki deneyler konusunda temel gerilim, bu deneyler sonucunda insan deneklerin uğrayabileceği zararlar ile bilim ve tüm insanlık için sağlanabilecek yararlar arasındadır. Bu yararlardan vazgeçmeden, ama söz konusu deneklere de zarar vermeden ilerleyebilmek için, birtakım bilimsel ve ahlaki kod ve kurallar geliştirilmiş, bunlar etik bildirgelerde ve hukuki mevzuatta ilan edilmiştir. Söz konusu deney ve araştırmalarda gerçekleşen değişikliklere paralel olarak, bu metinler de yeni gereksinimlere göre tadil edilmekte ya da bunlara yenileri eklenmektedir. Örneğin Helsinki Bildirgesi bugüne dek yedi kez revize edilmiştir. Sistematik bir derleme olan bu makale, insan denekli araştırmalarla ilgili ulusal ve uluslararası geçerlilikteki bu etikolegal metinleri bir yerde toplayan bir kaynak olmak amacındadır.

Anahtar Sözcükler. insan üzerindeki deneyler; Helsinki Bildirgesi; Tuskegee sifilis deneyi; Guatemala deneyleri; Nürnberg Kodu; Hawaii Bildirgesi; Oviedo / Biyotıp Sözleşmesi; Hasta Hakları Yönetmeliği; Tıbbi Deontoloji Nizamnamesi; UNESCO; TCK.
\end{abstract}

\footnotetext{
Abstract

Due to the human experimentation conducted in the Nazi Germany in the past, the subsequent Tuskegee syphilis and Guatemala STD studies, and the ongoing clinical pharmaceutical trials, potential harms to and exploitation of human subjects have long been discussed as a serious problem. Especially during the trials held in Nuremberg regarding the human experimentation that had been conducted by Nazi scientists the important lack of an internationally binding regulatory code was recognized, and the Nuremberg Code was created and adopted by countries to fill this gap. Given the ongoing in vivo pharmaceutical trials, in vitro procedures, stem cell research, etc., more various and complicated scientific research than ever before is conducted today on humans and human cells and tissues. The main tension in the field of human experimentation is between potential harms to the human subjects and potential benefits for science and humanity. A variety of scientific and ethical codes and rules have been developed and declared both in ethical declarations and in legal regulations in order to proceed to achieve these benefits without harming the subjects. In parallel with changes in these trials and research, these texts have also been either modified or supplemented by new texts. The Helsinki Declaration, for instance, has been revised for seven times up to the present. This systematic review aims to provide a source that gathers these nationally and internationally binding ethicolegal texts concerning human experimentation.

Keywords: human experimentation; Helsinki Declaration; Tuskegee syphilis experiment; Guatemala experiments; Nuremberg Code; Hawaii Declaration; Oviedo Convention; Republic of Turkey's 1998 Regulation on Patient Rights; Republic of Turkey's 1960 Regulation on Medical Deontology; UNESCO; Turkish Penal Code.
}

Hakan Ertin, M. Kemal Temel

İstanbul Tıp Fakültesi,

Tip Tarihi ve Etik AD.
Geliş Tarihi /Received : 31.07 .2016 Kabul Tarihi /Accepted: 04.09.2016

Sorumlu Yazar/Corresponding Author Doç. Dr. Hakan Ertin

İstanbul Tıp Fakültesi, Tıp Tarihi ve Etik AD; Hulusi Behçet Kütüphanesi, kat 2; 34093 İstanbul.

E-mail: hakanertin@gmail.com 


\section{GíRiş}

İnsan üzerindeki tıbbi deneylerin tarihi antikiteye dek uzanmaktadır; İskenderiyeli anatomistler Herofilos ve Erasistratos, insan kadavraları üzerinde diseksiyonlar gerçekleştirmiştir. Birkaç yüzyıl sonra Avrupa ve dolayısıyla Batı tıbbı karanlık Orta Çağ’a girmiş ve ilerleyişine yaklaşık bin yıllık bir ara vermiştir. Ancak antik anatomik bulgular, içinde Herofilos ve Erasistratos'tan geniş alıntılar bulunan Galen'in eserleri sayesinde tarihe karışmaktan kısmen kurtulmuştur (1). Avrupa, bilindiği üzere Orta Çağ sonrasında bir aydınlanma sürecine girmiş, bu gibi eserler sayesinde antik dönemin diseksiyon gibi müspet metotlarına, ampirik ve bilimsel yönteme yeniden rağbet etmiştir. Tibbi bilgi birikimini geliştirmek amacıyla gözleme ve deneye dayanan bu eski ama yeni yaklaşım, tıbbın diğer alanlarında da benimsenmiştir. Bilimin ilerleyiş hızı ve insanlar üzerindeki deneylerin sıklığı birbiriyle doğru orantılı bir biçimde artmıştır. Bununla birlikte, yirminci yüzyılın ilk yarısına gelindiğinde aşağıdaki gibi nedenlerden ötürü bu deneylerin giderek kabul edilemez, hatta vahşi bir hal aldığı görülmektedir:

- $\mathrm{Bu}$ dönemde gerek ulusal mevzuatlarda gerekse uluslararası arenada insan üzerindeki deneyleri düzenleyici etik kılavuz ve bildirgelerin olmayışı,

- Savaşlarla (Birinci ve İkinci Dünya Savaşı) geçen bu dönemde her alandaki denetimsizlik,

- Savaş esirleri ya da etnik gruplar üzerinde, insan bedeninin zayıflıklarını ve sınırlarını keşfederek düşmana karşı kullanılabilecek silahlar geliştirmek gibi, askeri amaçlarla gerçekleştirilen deneyler,

- Savaş esirleri ya da etnik gruplar üzerinde birtakım tedavilerin (örneğin sitma, kolera, tifo gibi hastalıklara karşı) ya da ilaçların (örneğin sülfonamit) etkisini test etmek amacıyla gerçekleştirilen deneyler (2).

İkinci Dünya Savaşı yıllarında yukarıdaki gibi nedenlerle insanlar üzerinde insanlık dışı deneyler gerçekleştiren Nazi bilim adamları savaş sonrasında Almanyảnın Nürnberg kentinde yargılanmış, toplama kamplarındaki birçok esiri acı içinde öldürmekle suçlanmıştır. Bu kişiler savunmalarında, deneylerinin hangi yasaya göre suç teşkil ettiği sorusuna yer vermiş ve deneylerini yasa dışı kılan uluslararası bir yasal düzenlemenin mevcut olmadığına işaret etmişlerdir. Bunun üzerine "yasal bir tıbbi araştırma”nın nasıl ola- cağını tanımlayan on ilke geliştirilmiş, bu ilkeler söz konusu duruşmaların gerçekleştiği kentin (Nürnberg) adıyla anılmıştır. Bu alandaki boşluğu doldurmak, insanlar üzerindeki deneyleri düzenlemek, insan onuruna ve insanlığa aykırı benzer uygulamaları engellemek amacıyla, Nürnberg Kodu (İlkeleri) ${ }^{*} 1947$ 'de uluslararası bir bildirge olarak ilan edilmiş, aynı konudaki müteakip bildirgeler için de bir temel oluşturmuştur.

Yirminci yüzyılın ikinci yarısında da insanlar üzerinde insanlık dışı deneyler gerçekleştirilmiştir; Nazi deneyleri kadar usulsüz olan bu araştırmaların en meşhur örneği 1932-1972 yılları arasında ABD'de sifilisin doğal seyrini izlemek amacıyla onam alınmaks1zın Siyahiler üzerinde gerçekleştirilmiş olan Tuskegee sifilis deneyidir.

Diğer yanda "usulünce" gerçekleştirilen deneyler de devam etmiştir; örneğin farmakolojinin gelişimine eşlik eden ilaç araştırmaları bugün de yürütülmektedir, sıklıkla tartışmalara konu olmalarına karşın. İnsan üzerindeki deneylere karşıt etik argümanlarda bu deneylerin;

- insan onuruna aykırılığına,

- insan sağlığına olası olumsuz etkileri nedeniyle tıp etiğinin zarar vermeme ilkesine aykırılığına,

- bilgilendirilmiş onamla ilgili problemler nedeniyle -plasebo kullanımı içeren deneyler başta olmak üzere- tıp etiğinin özerklik ilkesine aykırılığına,

- küçükler, gebeler, kısıtlllar ve zihnen yetersiz kişiler gibi kolay incinir ve onam veremez gruplar üzerinde gerçekleştirildiklerinde yarattıkları problemlere,

- az gelişmiş ülkelerdeki insanlar üzerinde gerçekleştirildiklerinde uluslararası etik bildirge ve standartlara uygunluktaki eksikliklerine odaklanılmaktadır.

$\mathrm{Bu}$ argümanların karşısındaki temel argüman ise, her gruptan insan üzerindeki klinik araştırmaların bilimin ilerleyişi için elzem olduğudur. Böylece, insan üzerindeki deneyler konusundaki temel gerilim, bu deneyler sonucunda insan deneklerin uğrayabileceği zararlar ile bilim ve tüm insanlık için sağlanabilecek yararlar arasındadır.

\footnotetext{
* Ya da Nürnberg Tip Etiği İlkeleri. Savaş suçları ile ilgili "Nürnberg İlkeleri” ile karıştırılmamalıdır.
} 


\section{INSANLAR ÜZERINDEKI DENEYLERLE İL- GILLI ULUSLARARASI DÜZENLEMELER}

Belirtildiği üzere, Nürnberg Kodu (İlkeleri) 1947'de uluslararası bir bildirge olarak ilan edilmiş, aynı konudaki müteakip bildirgeler için bir temel oluşturmuştur. Dünya Tabipler Birliği’nin 1964 tarihli Helsinki Bildirgesi, insan üzerindeki deneylere mahsus, bir diğer çığır açıcı metindir. Bu ikisine ve bu konu ile ilgili maddeler içeren öteki önemli metinlerin bir kısmına aşağıda değinilmiştir.

\subsection{Nürnberg Kodu}

İkinci Dünya Savaşı’nın ardından insanlar üzerindeki Nazi deneylerinden hareketle ve insanlar üzerindeki deneylere dair etikolegal boşluğu doldurmak üzere geliştirilen Nürnberg ilkeleri aşağıdaki gibi olmuştur (3) ${ }^{* *}$ :

1. İnsan denek kesinlikle özgür iradesiyle onam vermelidir.

Yani deneye katılan kişi; [1] hukuken onam verme ehliyetine sahip olmalıdır, [2] herhangi bir yaptırım, aldatmaca, yalan, tehdit ya da gizliden uygulanan başka bir kısıtlama ya da baskı unsuruna maruz kalmadığı özgür seçimlerde bulunabileceği bir konumda olmalıdır, ve [3] konu hakkında, bilgilendirilmiş ve bilinçli bir karar verebileceği kadar bilgi edinmiş ve bunları anlamış olmalıdır. Bu şartlardan sonuncusu, deneğin [deneye katılmaktan yana,] olumlu kararını kabul etmeden önce ona; deneyin doğasını, süresini ve amacını, deneyin hangi yöntem ve araçlarla gerçekleştirileceğini, mantıken beklenebilecek tüm külfet ve tehlikeleri, ve de deneye katılmanın sağlığı ya da bedeni üzerindeki olası etkilerini bildirmiş olmayı gerektirir.

[Denek tarafından verilen] onamın kalitesini saptama görevi ve sorumluluğu; deneye önayak olan, deneyi yöneten ya da deneyde görev alan her birey için mevcuttur. Bu, cezalandırılmadan bir başkasına havale edilemeyebilecek bir görev ve sorumluluktur. 2. Deneyle elde edilecek sonuçlar; lüzumsuz ya da tesadüfi addedilemeyecek, başka yöntem ve çalışmalarla elde edilemeyecek ve toplumun yararına olacak türden sonuçlar olmalıdır.

** Nürnberg Kodu burada İngilizce aslından Türkçeye, Türkçe literatürdeki eksik-hatalı tercümelerinden kaçınmak için yazarlar tarafından bizzat çevrilmiştir. Çeviri için ABD Ulusal Sağlık Enstitüleri'nden (US NIH) temin edilen orijinal metin kullanılmıştır.
3. Deney, hayvanlar üzerindeki çalışmalardan elde edilen bulgular ve deney konusu hastalığa ya da soruna dair daha önceden bilinenler göz önünde bulundurulduğunda bu deney ile elde edilebileceği düşünülen sonuçlar gerekçesiyle gerçekleştirilmelidir ve buna göre dizayn edilmelidir.

4. Deney, [deneklere yaşatılmasından] kaçınılabilecek tüm fiziksel ve zihinsel izdırap ve hasarlardan kaçınılarak gerçekleştirilmelidir.

5. Deneyi yürüten doktorun aynı zamanda denek olduğu durumlar hariç, bir deneyin ölüm ya da sakatlığa yol açabileceğini düşünmek için ortada a priori bir neden varsa söz konusu deney gerçekleştirilmemelidir.

6. Bir deneyde girilecek riskin düzeyi, hiçbir zaman deney konusu sorunu çözmenin insanlık için önemine göre belirlenecek düzeyden fazla olmamalıdır.

7. Düşük yaralanma, sakatlık ve ölüm olasılıklarına karşı dahi denekleri korumak için gereğince hazırlanılmalı, bunun için gereken ortam ve ekipman sağlanmalıdır.

8. Deney yalnızca bilimsel açıdan yetkin kişilerce gerçekleştirilmelidir. Deneyi yürütecek ya da deneyde görev alacak kişilerin deneyin her aşamasında son derece becerikli ve dikkatli olmaları şart koşulmalıdir.

9. Deney sırasında insan denek fiziksel ya da zihinsel açıdan deneye devam edemeyeceği bir noktaya gelirse deneye son vermekte özgür olmalıdır.

10. Deneyin başındaki bilim adamı, kendisinden beklenen dürüstlüğü, becerikliliği ve titiz muhakemeyi gösterirken deneye devam etmenin bir nedenle deneğin incinmesine, sakatlanmasına ya da ölmesine yol açacağını düşünecek olursa, deneyi sonlandırmaya hazır olmalıdır.

\subsection{Helsinki Bildirgesi}

Nürnberg Kodu’nun ardından 1964’te, insan üzerindeki klinik araştırmalarda uyulacak tıbbi ve etik standartları bildirmek üzere, Dünya Tabipler Birliği (The World Medical Association) tarafından Helsinki Bildirgesi ilan edilmiştir. Helsinki Bildirgesi’nde Nürnberg Kodu’nun yukarıda görülebileceği gibi “doğru ancak uygulanabilirliği az" maddeleri daha gerçekçi bir yaklaşımla ele alınmış, detaylandırılmış ve bir miktar esnetilmiştir. Bildirge 1975, 1983, 1989, 1996, 2000, 2008 ve 2013 'te olmak üzere, ilan tarihinden itibaren yedi kez revize edilmiştir. Bu majör revizyonların yanı sıra, 2002 ve 2004 'te eklenen açıklama notları ile me- 
tin üzerinde minör değişiklikler de yapılmıştır. 1975’te Tokyo'da gerçekleştirilen ilk revizyonda deneklerin sağlı̆̆ının bilimsel ilerlemeden önce geldiği vurgulanmış, araştırmaları denetleyecek bağımsız etik kurulların oluşturulması önerilmiştir. 1983'te Venedik’te gerçekleșen ikinci revizyonda, eğer olanaklıysa mutlaka çocuklardan da onam alınması vurgulanmıştır. 1989'da Hong Kong’taki üçüncü revizyonda deneyin, gerçekleştirilmekte olduğu ülkenin ulusal yasal mevzuatına uygun olması gerektiği belirtilmiştir. 1996 'da Güney Afrika’daki dördüncü revizyonda bildirgeye, etkililiği kanıtlanmış bir profilaktik, diyagnostik ya da terapötik yöntem söz konusu olmadığında çalışmalarda plasebo kullanılabileceği ifadesi eklenmiştir. Bununla birlikte 2000'de Edinburg'taki beşinci revizyonda plasebo kullanımının mümkün olduğunca sınırlı tutulması gerektiğinin altı çizilmiştir. 2002'de Washington'da eklenen açıklama paragrafında plasebo kullanıma, metodolojik nedenlerle bilimsel araştırmada plasebo kullanmak şart olduğunda ve de plasebo kullanılan kişilerin ciddi ve irreverzibl bir zarara uğrama ihtimali olmadığında başvurulabileceği açıklanmıştır. 2004'te Tokyoda ise bildirgeye kişilere araştırma sonrasında sağlanacak bakım ile ilgili bir açıklama eklenmiştir. Nürnberg Kodu’ndan geliştirilerek 1964'te ilan edilmiş ve ilanının ardından uzun yıllar klinik araştırmaların nasıl gerçekleştirileceği ile ilgili temel kılavuz olmuş olan Helsinki Bildirgesi, 2008'de altınc1, 2013'te yedinci kez revize edilmiştir. Uluslararası geçerlilikteki Helsinki Bildirgesi, ulusal mevzuatlarda da (örneğin, Türkiyede 1993 tarihli İlaç Araştırmaları Hakkında Yönetmelik’te) esas alınan, oldukça belirleyici bir metin olmuştur. Araştırmanın/deneyin gerçekleştirilme nedenleri, deneklerin deneye özgür iradeyle katılımı, deneyden önce deneklerden bilgilendirilmiş onam alımı, insan (ve hayvan) deneklerin esenliğine gösterilecek özen, deney protokolüne, bulgularına ve sonuçlarına dair raporların araştırma etik kurullarına ibrazı, deneyin ulusal ve uluslararası yasal düzenlemelere uygunluğu, çocuklar ve zihnen yetersiz denekler üzerinde gerçekleştirilecek deneylerde gözetilecek kriterler, ve deneylerde plasebo kullanımı gibi konulara dair, Helsinki Bildirgesi'nin 2013 versiyonundan aşağ1daki maddeler örnek verilebilir (4):

\section{Genel ilkeler}

5. Tipta ilerleme, sonuçta insanlar üzerinde yapılan çalışmaları da içeren araştırmalara bağlıdır.

9. Üzerinde araştırma yapılan kişilerin yaşamını, sağlığını, onurunu, kişilik bütünlüğünü, kendi kararını verme hakkını, özel yaşamını ve kişisel bilgilerinin gizliliğini korumak, tıbbi araştırmalarda yer alan hekimlerin görevidir. Üzerlerinde araştırma yapılan kişilerin korunması yükümlülüğü her zaman hekime ve diğer sağlık çalışanlarına ait olmalı, kendileri buna onam vermiş olsalar bile bu yükümlülük asla üzerlerinde araşıtırma yapılan kişilere bırakılmamalıdır.

12. İnsanların kullanıldığı tıbbi araştırmalar, yalnızca etik ve bilim açısından yeterli eğitime, yetişmişliğe ve niteliklere sahip kişilerce yapılmalıdır. Hastalar ya da sağlıklı gönüllüler üzerinde yapılacak araştırmalar, yetkin ve gerekli niteliklere sahip bir hekimin ya da sağlık çalışanının denetiminde gerçekleştirilmelidir. 13. Tibbi araştırmalarda yeterince temsil edilmeyen gruplara araştırmalara katılım için gerekli erişim olanağı sağlanmalıdır.

14. Tibbi araştırma ile sağlık hizmetini birlikte yürüten hekimler, bunun ancak koruyucu, tanı koydurucu ya da tedavi edici yönden değerli olabileceği durumlarda ve araştırma kapsamına alınan hastaların sağlığının bu durumdan olumsuz etkilenmeyeceği konusunda makul gerekçelere sahip olmaları halinde hastalarını araştırmalarına dahil etmelidirler.

\section{Riskler, yükler ve yararlar}

16. Tibbi uygulamalarda ve tıbbi araştırmalarda, girişimlerin çoğu risk ve yük taşır. İnsanlar üzerindeki tıbbi araştırmalar, ancak, amacın taşıdığı önem, üzerinde araştırma yapılan kişilerin maruz kalacakları risklere ve üstlenecekleri yüklere ağır bastığında yapilmalıdir.

18. Hekimler, risklerin yeterince değerlendirildiğine ve bunların tatmin edici biçimde yönetilebileceğine kani olmadıkları sürece insanlar üzerinde yapılan araştırmalarda yer almamalıdırlar. Risklerin potansiyel yararlara ağır bastığının görüldüğü durumlarda ya da kesin sonuçlara ilişkin yeterli kanıtlar elde edildiğinde, hekimler çalışmaya devam etme, çalışmayı değiştirme ya da hemen durdurma seçeneklerini değerlendirmelidir.

\section{Savunmasız gruplar ve kişiler}

20. Savunmasız durumdaki bir grupla yapılacak tıbbi araştırma, ancak, araştırmanın bu grubun sağlık gereksinimlerine ya da önceliklerine karşılık geleceği ve araştırmanın bu konumda olmayan başka bir grupla yapılmasının mümkün olmadığı durumlarda 
haklı çıkarılabilir. Ek olarak, söz konusu grup araştırmadan elde edilen bilgilerden, uygulamalardan ya da girişimlerden yararlanabilmelidir.

\section{Bilimsel gereklilikler ve araştırma protokolleri}

21. İnsanlar üzerinde yapılan tıbbi araştırmalar genel olarak kabul edilen bilimsel ilkelere uygun olmalı; eksiksiz bir bilimsel literatür bilgisine, ilgili diğer bilgi kaynaklarına, yeterli laboratuvar olanaklarına ve ilişkili ise hayvan deneylerine dayanmalıdır. Araştırmada kullanılan hayvanların iyilik halinin sağlanmasına özen gösterilmelidir.

\section{Araştırma etik kurulları}

23. Araştırma protokolü, araştırma başlamadan önce, değerlendirmesi, yorumda bulunması, yol göstermesi ve onay vermesi için ilgili araştırma etik kuruluna sunulmalıdır. Bu kurul işleyişinde saydam olmalı; araştırmacıdan, destekleyicilerden ya da başka herhangi bir dıș etkiden bağımsız kalmalı ve değerlendirme için gerekli nitelikleri taşımalıdır. Kurul, ilişkili uluslararası norm ve standartları olduğu gibi, araştırmanın yapılacağı ülkenin ya da ülkelerin yasa ve yönetmeliklerini de göz önünde bulundurmalı, ancak bunların, üzerinde araştırma yapılan kişilere bu Bildirge ile sağlanan korumaları zayıflatmasına ya da ortadan kaldırmasına izin verilmemelidir. Kurul, sürmekte olan çalışmaları izleme hakkına sahip olmalıdır. Araştırmacı, özellikle ortaya çıkan herhangi bir ciddi olumsuz sonuç başta olmak üzere Kurul'a izleme bilgileri sunmalıdır. Kurul'un incelemesi ve onayı olmaksızın protokolde hiçbir değişiklik yapılmamalıdır. Çalışmanın bitiminde, araştırmacılar, çalışmanın bulgularını ve sonuçlarını içeren bir raporu Kurul'a sunmalıdırlar.

\section{Aydınlatılmış onam}

25. Aydınlatılmış onam verme yeterliği olan kişilerin araştırmaya katılımları, gönüllülük temelinde olmalıdır. Aile üyelerine ya da toplum lideri konumunda olan kişilere danışılması uygun olsa bile, aydınlatılmış onam verme yeterliğine sahip kimse, kendi özerk kararı olmadan araştırmaya dahil edilmemelidir.

27. Hekim, bir araştırmada kullanılacak kişilerden aydınlatılmış onam alırken, katılımcı adayının kendisiyle bağımlılık ilişkisi olup olmadığı ya da onayın belirli bir zorunlulukla istemeden verilip verilmediği gibi konulara özellikle dikkat etmelidir. Böyle durumlarda aydınlatılmış onam, bu tür ilişkilerin tamamen dışındaki, uygun niteliklere sahip bir başkası tarafından alınmalıdır.

28. Aydınlatılmış onam verme yeterliği olmayan bir katılımcı adayı söz konusu olduğunda, hekim bu kișinin yasal temsilcisinden onam almalıdır. Araştırmanın katılımcı adayı tarafindan temsil edilen bir grubun sağlık açısından yararını gözetmesi, aynı araştırmanın aydınlatılmış onam verme yeterliği olan kişilerle yapılmasının mümkün olmaması ve araştırmanın katılımcıya sadece en az derecede risk ve yük getirmesi koşullarının sağlandığı durumlar dışında, onam verme yeterliği bulunmayan bireyler üzerinde araştırma yapılmamalıdır.

32. Biyo-bankalarda ya da benzeri yerlerde bulundurulan materyal ya da veriler gibi tanımlanabilir insan materyali ya da verileri kullanılarak yapılacak tıbbi araştırmalar söz konusu olduğunda hekimler, bunların toplanması, depolanarak saklanması ve/veya yeniden kullanımı için aydınlatılmış onam almalıdır. Bu tür araştırmalar için onam almanın olanaksız ya da gerçekleştirilmesi çok güç olduğu bazı istisnai durumlar olabilir. Böyle durumlarda araștırma, ancak araştırma etik kurulunun konuyu incelemesi ve onayı üzerine yapılabilir.

\section{Plasebo kullanımı}

33. Yeni bir tıbbi girişimin yararları, riskleri, yükleri ve etkililiği, aşağıda belirtilen durumlar dışında, kanıtlanmış en iyi yöntemle karşılaştırılarak denenmelidir: Kanıtlanmış bir girişimin bulunmadığ durumlarda plasebo kullanımı ya da hiç girişimde bulunmama kabul edilebilirdir; veya, kanıtlanmış en iyi yöntemden daha az etkili bir girişimde bulunmanın ya da plasebo kullanmanın ya da hiç girişimde bulunmamanın bir girişimin etkililiği veya güvenliğini saptamak için gerekli olduğuna ilişkin ikna edici ve bilimsel açıdan sağlam yöntemsel gerekçeler bulunduğunda ve kanıtlanmış en iyi yöntemden daha az etkili girişim uygulanacak ya da plasebo verilecek ya da hiç girişimde bulunulmayacak hastaların kanıtlanmış en iyi girişimin uygulanmamasına bağlı olarak ek bir ciddi ya da geri-dönüşsüz zarara uğramayacak olmaları halinde.

Bu seçeneğin kötüye kullanılmaması için azami dikkat gösterilmelidir

Klinik uygulamalarda kanıtlanmamış girişimlerin kullanımı

37. Kanıtlanmış bir girişimin bulunmadığ ya da bilinen diğer girişimlerin etkisiz kaldığ tedavisinde hekim, uzman görüşünü aldıktan sonra, hastanın ya da yasal temsilcisinin aydınlatılıış onamıyla, yaşam kurtarabileceğini, sağlığı geri getirebileceğini ya da acıları hafifletebileceğini düşündüğü henüz kanıtlanmamış bir girişimi uygulayabilir. 


\subsection{Birleşmiş Milletler Medeni ve Siyasi Hak- lar Sözleşmesi}

İnsan hak ve özgürlüklerini korumayı amaçlayan, 16 Aralık 1966 tarihinde Birleşmiş Milletler tarafından kabul edilerek imza ve onaya açllan, 23 Mart 1976 tarihinde yürürlüğe giren ve Türkiye Cumhuriyeti tarafindan 15 Ağustos 2000 tarihinde imzalanan Birleşmiş Milletler Medeni ve Siyasi Haklar Sözleşmesi’nin yedinci maddesi şöyledir (5):

Hiç kimse işkenceye ya da zalimane, insanlık dışı ya da küçük düşürücü muamele ya da cezalandırmaya maruz bırakılamaz. Özellikle, hiç kimse kendi özgür rızası olmadan tıbbi ya da bilimsel deneylere tabi tutulamaz.

\subsection{Hawaii Bildirgesi}

Psikiyatrik hastaların gerek zorla gerekse onama dayalı tedavisi, psikoterapist ile hasta arasındaki ilişki, psikiyatrik hastadan bilgilendirilmiş onam alımı, hasta mahremiyeti gibi konularda Dünya Psikiyatri Birliği (The World Psychiatric Association) tarafından benimsenen etik kodları bildirmek üzere 1977'de ilan edilen Hawaii Bildirgesi’nde, psikiyatrik hastalarla yürütülecek deneylere de değinilmiştir. Tıbbın diğer branşlarında olduğu gibi, psikiyatrik araştırmalara katılacak deneklere de araştırmanın amaçları ve tahmin edilen riskleri, yararları ve sonuçları bildirilmeli, denek buna göre onam vererek araştırmaya katılmalı, klinik araştırma sadece tahmin edilen yararlar risklere ağır bastığında başlatılmalıdır. Hawaii Bildirgesi'nin konu ile ilgili dokuzuncu maddesi aşağıdaki gibidir (6):

...Terapide olduğu gibi klinik araştırmalarda da, her hastaya mevcut en iyi tedavi sunulmalıdır. Projenin içerdiği sakıncalar, riskler, işlemler ve amaçlar hakkındaki tüm bilgi hastaya verildikten sonra, hastanın katılımı gönüllü olmalıdır...

\subsection{Avrupa Konseyi İnsan Hakları ve Biyotıp Sözleşmesi}

"Biyoloji ve Tibbın Uygulanması Bakımından İnsan Hakları ve İnsan Haysiyetinin Korunması Sözleşmesi: İnsan Hakları ve Biyotıp Sözleşmesi” ya da “Oviedo Sözleşmesi” adlarıyla da bilinen, 4 Nisan 1997 tarihinde imzaya açılan ve Türk iç hukukunda ayrıca yasa olarak kabul edilip 2004'te yürürlüğe giren Avrupa Konseyi İnsan Hakları ve Biyotıp Sözleşmesi, biyoetiğin başlıca konuları üzerine ilk uluslararası anlaşma olduğu için önemli bir metindir. Avrupa Konseyi İnsan Hakları ve Biyotıp Sözleşmesi, hukuken bağlayıcı bir sözleşmedir ve sözleşme hükümlerinin ihlali halinde yaptırımlar öngörülmüştür $(7,8)$. Sözleşmede standartlara ve mesleki yükümlülüklere uygunluk, tıbbi müdahaleler için bilgilendirilmiş onam alımı, genetik bilimi ve insan genomuyla ilgili müdahaleler gibi konuların yanı sıra, beşinci bölümde bilimsel araştırmalar ele alınmış ve aşağıdaki kriterler belirlenmiştir (9):

\section{Bölüm V: Bilimsel araştırma}

Madde 15 - Genel kural

Biyoloji ve tıp alanında bilimsel araştırma, bu Sözleşme hükümlerine ve insan varlığının korunmasını güvence altına alan diğer yasal hükümlere bağlı kalmak kaydıyla, serbestçe yapılabilir.

Madde 16 - Üzerinde araştırma yapılan kişilerin korunmas1

Bir kimse üzerinde araştırma, ancak aşağıdaki şartların tümünün yerine getirilmesi halinde yapılabilir: i) insanlar üzerindeki araştırmayla karşılaştırılabilir etkinlikte başka bir seçeneğin bulunmaması;

ii) araştırmaya konu olan şahsın maruz kalabileceği tehlikelerin, araştırmanın beklenen yararlarıyla oransız olmamasi;

iii) araştırma projesinin bilimsel değerinin, araştırma amacının öneminin değerlendirilmesi ve etik bakımdan kabul edilebilirliğinin çok disiplinli bir gözden geçirmeye tabi tutulması dahil, yetkili bir kurum tarafından bağımsız bir şekilde incelenmeden sonra onaylanmış olması;

iv) üzerinde araştırma yapılan kişilerin, korunmaları için kanun tarafından öngörülen hakları ve güvenceleri hakkında bilgilendirilmiş olmaları;

v) 5. maddede öngörülmüş bulunan muvafakatin açıkça ve belirli bir şekilde verilmiş olması ve bunun belgelendirilmiş bulunması. Bu muvafakat her zaman serbestçe geri alınabilir.

Genel kriterler yukarıda görüldüğü gibidir; bilgilendirilmiş onam alınamayan hastaların bilimsel araştırmalara katılımına ve embriyo(n) üzerindeki araştırmalara dair ise aşağıdaki maddeler bulunmaktadır (9):

Madde 17 - Araştırmaya muvafakat etme yeteneği olmayan kişilerin korunması

1. 5. maddede belirtildiği şekilde muvafakatini açılama yeteneği bulunmayan bir kimse üzerinde araştırma ancak, aşağıdaki şartların tümünün yerine getirilmesi halinde yapılabilir: 
i) Madde 16 alt paragraf (i)'den (v)'e kadar olan şartların gerçekleşmiş olması;

ii) araştırmanın sonuçlarının ilgilinin sağlığı üzerinde gerçek ve doğrudan yarar sağlama beklentisinin bulunmasi;

iii) muvafakat etme yeteneği bulunan bireyler üzerinde karşılaştırılabilir nitelikte bir etkinlik doğuracak bir araştırmanın yapılamaması;

iv) Madde 6'da öngörülen gerekli iznin belirli ve yazılı olarak verilmiş bulunması ve

v) ilgili kişinin itirazda bulunmaması.

2. Araştırmanın ilgilinin sağlığı üzerinde doğrudan yararlı sonuçlar sağlayacağ diğ 1 durumlarda, istisnai olarak ve kanun tarafindan öngörülen koruyucu şartlar altında, söz konusu araştırmaya, yukarıda 1. paragraf ve alt paragraf (i), (iii), (iv) ve (v)'de öngörülen şartlarla birlikte aşağıdaki ek şartların da bulunması halinde izin verilebilir:

i) araştırmanın, hastanın sağlık durumu, hastalığ veya rahatsızlığı hakkındaki bilimsel bilginin önemli derecede geliştirilmesine katkıda bulunma yoluyla, ilgili kişiye veya aynı yaş grubunda olan veya aynı hastalık ya da rahatsızlığa yakalanmış bulunan veya aynı durumda olan diğer kimselere yarar sağlamaya elverişli nihai sonuçlara ulaşılması amacını taşıması; ii) araştırmanın, ilgili kişi bakımından sadece asgari bir tehlike ve asgari bir külfeti gerektirmesi

Madde 18 - Tüpte embriyonlar üzerinde araştırma 1. Hukukun embriyon üzerinde tüpte araştırmaya izin vermesi halinde, embriyon için uygun koruma sağlanacaktır.

2. Sadece araştırma amaçlarıyla insan embriyonlarının yaratılması yasaktır.

\subsection{UNESCO İnsan Genomu ve Hakları Ev- rensel Bildirgesi}

1997 tarihli UNESCO İnsan Genomu ve Hakları Evrensel Bildirgesi'nin konuyla ilgili maddelerinden alıntılanan aşağıdaki kısımlar ile Helsinki Bildirgesi ilkeleri arasında belirgin bir paralellik gözlemlenebilir (10):

\section{Madde 5}

a) Bireyin genomunu etkileyecek bir araştırma, tedavi veya tanı girişimi ancak olası risk ve yararların önceden ve titizlikle değerlendirilmesinden sonra ve iç hukukun bütün diğer gereklerine uyularak yapılabilir. d) Araştırmalarda, bunlara ek olarak protokoller, ilgili ulusal ve uluslararası kural ve ilkelere uygun olarak ön değerlendirmeye tabi tutulmalıdır. e) Eğer yasaya göre bir bireyin onam vermesi için yeterliliği yoksa bireyin genomu üzerinde araştırma, sadece onun sağlığına doğrudan yararlı olacaksa, yasada öngörülen yetki ve koruyucu hükümlere uygun olarak yürütülebilir. Sağlığa doğrudan yarar sağlama beklentisi olmayan bir araştırma ancak istisnai durumlarda, büyük bir özenle, bireyi en az risk ve sıkıntıya sokacak bir şekilde ve ancak araştırma aynı yaş grubu veya aynı genetik yapıda olan bireylerin sağlığına yarar sağlamayı amaçlıyorsa ve yasanın koyduğu hükümlere bağlı olarak ve ilgili bireyin bireysel haklarının korunması koşulu ile yapılabilir.

\section{Madde 10}

Özellikle biyoloji, genetik ve tıp alanlarında insan genomu ile ilgili olarak yürütülecek hiçbir araştırma ya da uygulama, insan haklarına, temel özgürlüklere, bireylerin veya insan topluluklarının onuruna gösterilen saygıdan daha üstün değildir.

\section{Madde 11}

Üremeye yönelik insan klonlaması gibi insan onuruna aykırı uygulamalara izin verilemez. Devletler ve yetkili uluslararası örgütler böyle uygulamaların ortaya çıkarılması ve bu Bildirgede ortaya konan ilkelere uygun olarak gerekli önlemlerin ulusal veya uluslararası düzeyde alınması amacıyla işbirliği yapmaya çağrılmaktadır.

\subsection{Diğer}

Tuskegee skandalının ardından ABD'de insan denekleri korumak amaciyla kurulan komisyon (The National Commission for the Protection of Human Subjects of Biomedical and Behavioral Research) tarafindan hazırlanan 1979 tarihli Belmont Raporu ile (11), Uluslararası Tip Bilimleri Örgütleri Konseyi (The Council for International Organizations of Medical SciencesCIOMS) ve Dünya Sağlik Örgütü işbirliğiyle hazırlanan 1993 ilan ve 2002 revizyon tarihli İnsan Denekler İçeren Biyomedikal Araștırmalar İçin Uluslararası Etik Kılavuz (12), insan üzerindeki deneylere dair metinlerin diğer örnekleridir.

\section{3. İNSANLAR ÜZERINDEKI DENEYLERLE İGILII ULUSAL MEVZUAT}

İnsan üzerindeki deneylere ilişkin Türkçe mevzuat fakir değildir; bu konu çeşitli düzenleme, genelge ve yönetmeliklerde ve ayrıca ceza hukukunda ele alınmiştır. 


\subsection{Düzenleme, Genelge ve Yönetmelikler}

Türkiye'de birçok yönetmeliğin bir bölümünde ya da bütününde insan üzerindeki deneyler ele alınmaktadır. Bu metinler birbiri üzerine temellendirilmiştir; örneğin, 1998 tarihli Hasta Araştırmaları Yönetmeliği’nde 1993 tarihli İlaç Araştırmaları Hakkında Yönetmelik'e, 1993 tarihli İlaç Araştırmaları Hakkında Yönetmelik'te ise 1960 tarihli Tibbi Deontoloji Tüzüğü’ne ve Helsinki Bildirgesi’ne gönderme yapılmıştır. Türkiyede insan üzerindeki deneylerle ilgili ulusal mevzuatın temel taşlarını teşkil eden düzenleme, genelge ve yönetmeliklerin kronolojik bir listesi aşağıdaki gibidir:

- 19.2.1960-10436 tarihli Resmi Gazete'de yayımlanan Tibbi Deontoloji Nizamnamesi (13);

- 29.1.1993-21480 tarihli Resmi Gazete'de yayımlanan İlaç Araştırmaları Hakkında Yönetmelik (14);

- 27.5.1994-21942 tarihli Resmi Gazetede yayımlanan Farmasötik Müstahzarların Biyoyararlanım ve Biyoeşdeğerliğinin Değerlendirilmesi Hakkında Yönetmelik (15);

- T.C. Sağlık Bakanlığı İlaç ve Eczacılık Genel Müdürlüğünün 29.12.1995 tarih ve 51748 sayılı, "klinik araştırmalar" konulu genelgesi (16),

- ve bu genelgenin ekinde yayımlanan İyi Klinik Uygulamaları Kılavuzu (16),

- 28.1.2009 tarih ve 616 sayılı olur ile yürürlüğe giren İyi Klinik Uygulamaları Kılavuzu (17),

- 28.5.2010 tarih ve 3426 sayll olur ile yürürlüğe giren İyi Klinik Uygulamaları K1lavuzu (17),

- 10.12.2010 tarih ve 7697 sayılı olur ile yürürlüğe giren İyi Klinik Uygulamaları Kılavuzu (17),

- 23.8.2011 tarih ve 7481 sayılı olur ile yürürlüğe giren İyi Klinik Uygulamaları K1lavuzu (17),

- 6.12.2011 tarih ve 10990 sayılı olur ile yürürlüğe giren İyi Klinik Uygulamaları K1lavuzu (17),

- 17.4.2013 tarih ve 43020 sayılı olur ile yürürlüğe giren İyi Klinik Uygulamaları K1lavuzu (17),

- 15.7.2014 tarih ve 86401 sayılı olur ile yürürlüğe giren İyi Klinik Uygulamaları K1lavuzu (17),

- 13.11.2015 tarihli olur ile yürürlüğe giren İyi Klinik Uygulamaları Kılavuzu (17),
- yine bu genelgenin ekinde yayımlanan İyi Laboratuvar Uygulamaları Kılavuzu (16);

- 1.8.1998-23420 sayılı Resmi Gazete'de yayımlanan Hasta Hakları Yönetmeliği (18);

- 23.12.2008-27089 tarihli Resmi Gazete'de yayımlanan Klinik Araştırmalar Hakkında Yönetmelik (19),

- 19.8.2011-28030 tarihli Resmi Gazete'de yayımlanan Klinik Araştırmalar Hakkında Yönetmelik (20),

- 13.4.2013-28617 tarihli Resmi Gazete'de yayımlanan Klinik Araştırmalar Hakkında Yönetmelik (21);

- 25.06.2014-29041 tarihli Resmi Gazetede yayımlanan İlaç ve Biyolojik Ürünlerin Klinik Araştırmaları Hakkında Yönetmelik (22).

T.C. Sağlık Bakanlığı İlaç ve Eczacılık Genel Müdürlüğünün 29.12.1995 tarih ve 51748 sayıll, "klinik araştırmalar" konulu genelgesinin ekinde yayımlanan İi Klinik Uygulamalar Kılavuzu, sonrasında yukarıda görülen tarihlerde olmak üzere sekiz kez revize edilmiştir.

Klinik Araştırmalar Hakkında Yönetmelik'in (RG 23.12.2008-27089) 2008'de yürürlüğe girişi ile 1993 tarihli İlaç Araştırmaları Hakkında Yönetmelik (RG 29.1.1993-21480) yürürlükten kaldırılmıştır.

Sonrasında Klinik Araştırmalar Hakkında Yönetmelik de birkaç revizyon geçirmiştir: 2008 tarihli Klinik Araştırmalar Hakkında Yönetmelik, yine aynı adı taşıyan ve 19.8.2011-28030 tarihli Resmi Gazete'de yayımlanan Klinik Araştırmalar Hakkında Yönetmelik ile yürürlükten kaldırılmıştır. 2011 tarihli Klinik Araştırmalar Hakkında Yönetmelik, aynı adı taşıyan ve 13.4.2013-28617 tarihli Resmi Gazete'de yayımlanan Klinik Araştırmalar Hakkında Yönetmelik ile yürürlükten kaldırılmıştır. Daha sonra 2013 tarihli Klinik Araştırmalar Hakkında Yönetmelik'in içeriği tekrar değiştirilmiş ve yeni metin 25.06.2014-29041 tarihli Resmi Gazete'de bu kez İlaç ve Biyolojik Ürünlerin Klinik Araştırmaları Hakkında Yönetmelik adı altında yayımlanmıştır.

\subsubsection{Tıbbi Deontoloji Nizamnamesi}

19.2.1960-10436 tarihli Resmi Gazetede yayımlanan Tibbi Deontoloji Nizamnamesi'nin 11. maddesinde insanlar üzerinde yalnızca "tecrübe etmek" için bir tedavinin denenemeyeceği, ancak mevcut tedaviler faydasızsa önceden hayvanlarda tecrübe edilmiş olan ve mevcut seçeneklerden daha zararlı olmayan bir tedavinin denebileceği belirtilmiştir (13): 
Madde 11 - Tecrübe maksadı ile insanlar üzerinde hiç bir cerrahi müdahale yapılamayacağı gibi aynı maksatla kimyevi, fiziki veya biyolojik şekilde herhangi bir tedavi de tatbik edilemez.

Klasik metotların bir hastaya fayda vermeyeceği klinik veya laboratuvar muayeneleri neticesinde sabit olduğu takdirde daha önce, mutat tecrübe hayvanları üzerinde kafi derecede denenmek suretiyle faydalı tesirleri anlaşılmış olan bir tedavi usulünün tatbiki caizdir. Şu kadar ki, bu tedavinin tatbik edilebilmesi için, hastaya faydalı olacağının ve muvaffakiyet elde edilmemesi halinde ise mutat tedavi usullerinden daha elverişsiz bir netice alınmayacağının muhtemel bulunması şarttır.

Evvelce tecrübe edilmiş olmamakla beraber, zarar vermesine ihtimal bulunmayan ve hastayı kurtarması kati görülen bir müdahale yapılabilir.

\subsection{2. İlaç Araştırmaları Hakkında Yönetmelik}

29.1.1993-21480 tarihli Resmi Gazete'de yayımlanan İlaç Araştırmaları Hakkında Yönetmelik, Türkiye'de klinik araştırmalarla ilgili ilk mevzuat örneklerindendir. Türkiyede "etik kurullar” bu yönetmelikle birlikte ortaya çıkmış ve yaygınlaşmıştır (23). Yönetmelikte; klinik araştırmalarda uyulacak esaslara, bu araştırmaların dokümantasyonuna, bu araştırmaları etik yönden değerlendirecek merkezi ve yerel kurullara ve de bu kurulların kadrosuna ve görevlerine dair bilgiler verilmiştir. Yönetmeliğin sekizinci maddesinin ilk dört paragrafı aşağıdaki gibidir (14):

Madde: 8- İnsanlar üzerinde bilimsel amaçla ilaç kullanılarak yapılacak tıbbi araştırmaların yürütülmesinde aşağıdaki hususlara uyulur:

A İnsan üzerinde yapılacak ilaç araştırmalarında Helsinki Deklarasyonu ve ekleri kararlar ile Tibbi Deontoloji Tüzügü’ne tam olarak uyulur.

B) Dokuzuncu maddede belirtilen I., II., III. dönem denemeler, gönüllülerde ve kişinin yazılı rızası ile yapilir.

C) Yapılacak araştırmaların kapsamı, amacı, zarar ve tehlikeleri, gönüllülere tam ve yazılı olarak anlatılır.

D) Kesin bir zorunluluk olmadıkça, 18 yaşını tamamlamamış olanlar ile gebeler ve mümeyyiz olmayanlar üzerinde I. ve II. dönem ilaç denemeleri yapılmaz. III. dönem denemeler, velayet veya vesayet altında bulunanlar için, ancak veli ve vasilerinin yazilı muvafakati ile yapilır.

\subsubsection{Hasta Hakları Yönetmeliği}

1.8.1998-23420 sayılı Resmi Gazete'de yayımlanan Hasta Hakları Yönetmeliği'nin altıncı bölümünde tıbbi araştırmalar ele alınmış ve bu araştırmalar sırasında rıza (onam) alımı (madde 32), "gönüllü”nün korunması ve bilgilendirilmesi (madde 33), rızanın nasıl alınacağı (madde 34), küçüklerin ve mümeyyiz olmayanların durumu (madde 35 ) ve de ilaç ve terkiplerin araştırma amacıyla kullanımı (madde 36) konularına değinilmiştir (18):

Madde 32- Hiç kimse; Bakanlığın izni ve kendi r1zası bulunmaksızın, tecrübe, araştırma veya eğitim amaçlı hiçbir tıbbi müdahale konusu yapılamaz. Tıbbi araştırmalardan beklenen tıbbi fayda ve toplum menfaati, üzerinde araştırma yapılmasına rıza gösteren gönüllünün hayatından ve vücut bütünlüğünün korunmasından üstün tutulamaz. Tibbi araştırmalar, sadece, mevzuata göre araştırmada bulunmayan yetkili ve yeterli tıbbi bilgi ve tecrübeyi haiz olan personel tarafından, mevzuat ile belirlenmiş bulunan yerlerde yürütülür. Gönüllünün tıbbi araştırmaya rıza göstermiş olması, bu araştırmada görev alan personelin sorumluluğunu ortadan kaldırmaz.

Madde 33- Araştırmalarda, gönüllünün sağlığına ve diğer kişilik haklarına zarar verilmemesi için gereken bütün tedbirler alınır. Araştırmanın gönüllüye vereceği muhtemel zararlar önceden tespit edilemediği takdirde; gönüllü, rızası bulunsa dahi, araştırma konusu yapılamaz. Gönüllü; araştırmanın maksadı, usulü, muhtemel faydaları ve zararları ve araştırmaya iştirak etmekten vazgeçebileceği ve araştırmanın her safhasında başlangıçta verdiği rızayı geri alabileceği hususlarında, önceden yeterince bilgilendirilir.

Madde 34- Tıbbi araştırma hakkında yeterince bilgilendirilmiş olan gönüllünün rızasının maddi veya manevi hiçbir baskı altında olmaksızın, tamamen serbest iradesine dayanılarak alınmasına azami ihtimam gösterilir. Tıbbi araştırmalarda rıza yazılı şekil şartına tabidir.

Madde 35- Reşit ve mümeyyiz olmayanlara, kendilerine faydası olmadan, sırf tıbbi araştırma amacı güden tıbbi müdahaleler hiçbir surette tatbik edilemez. Faydaları bulunması şartı ile reşit ve mümeyyiz olmayanlar üzerinde tıbbi araştırma yapılması, velilerinin veya vasilerinin rızasına bağlıdır. Kanuni temsilci tarafindan muvafakat verilmeyen hallerde, 24 üncü maddenin ikinci fikrası hükmü uygulanır.

Madde 36- Özel mevzuatına göre izin veya ruhsat 
alınmış olsa dahi, sırf tıbbi araştırma amacı ile hasta üzerinde kendi rızası ve Bakanlığın izni bulunmaksızın hiçbir ilaç ve terkip kullanılamaz. İlaç ve terkiplerin tıbbi araştırmada kullanımı, 29/11/1993 [yazarlar tarafindan tashih: 23/1/1993] tarihli ve 21480 sayılı Resmi Gazete'de yayımlanan İlaç Araştırmaları Hakkında Yönetmelik hükümlerine tabidir.

\subsection{Yasalar}

Türkiye Cumhuriyeti Anayasası'nda tıbbi deneylere değinilmekte, Türk Ceza Kanunu’nda ise insanlar üzerindeki deneylerin suç teşkil etmeden gerçekleştirilebilmesi için sağlanması gereken kriterler belirtilmektedir.

\subsubsection{Anayasa}

Türkiye Cumhuriyeti Anayasası́nın on yedinci maddesine göre;

...Tibbi zorunluluklar ve kanunda yazılı haller $\mathrm{d}_{1}-$ şında, kişinin vücut bütünlüğüne dokunulamaz; r1zası olmadan bilimsel ve tıbbi deneylere tabi tutulamaz... (24).

\subsubsection{Türk Ceza Kanunu}

5237 sayılı Türk Ceza Kanunu'nun 77. maddesinin e bendinde "siyasal, felsefi, rrki veya dini saiklerle toplumun bir kesimini bir plan doğrultusunda sistemli olarak bilimsel deneylere tabi kılma" insanlığa karşı suçlardan biri kabul edilmiştir. Doksanıncı madde ise "insan üzerinde deney" başlığını taşımakta olup tamamen bu konuya ayrılmıştır (25). Maddenin ikinci fikrasına ait bentlerde insanlar üzerinde bilimsel bir deneyin cezai bir sonuç doğurmaksızın gerçekleştirilebilmesi için sağlanması gereken şartlar tanımlanmıştır. Bu şartlar uluslararası etik bildirgelerdeki ve klinik kılavuzlardaki kriterlere oldukça paraleldir. Yine uluslararası etik bildirge ve klinik kılavuzlarda olduğu gibi, çocuklar üzerinde gerçekleştirilecek deneylere maddenin üçüncü fikrasında ayrıca değinilmiştir ve bu pediyatrik deneyler için bazı ilave şartlar belirtilmiştir.

\section{Madde 90 - İnsan Üzerinde Deney}

(1) İnsan üzerinde bilimsel bir deney yapan kişi, bir yıldan üç yıla kadar hapis cezası ile cezalandırılır.

(2) İnsan üzerinde yapılan rrzaya dayalı bilimsel deneyin ceza sorumluluğunu gerektirmemesi için;

a) Deneyle ilgili olarak yetkili kurul veya makamlardan gerekli iznin alınmış olması,

b) Deneyin öncelikle insan dışı deney ortamında veya yeterli sayıda hayvan üzerinde yapılmış olması, c) İnsan dıșı deney ortamında veya hayvanlar üzerinde yapılan deneyler sonucunda ulaşılan bilimsel verilerin, varılmak istenen hedefe ulaşmak açısından bunların insan üzerinde de yapılmasını gerekli kılmas1,

d) Deneyin, insan sağlı̆̆ı üzerinde öngörülebilir zararlı ve kalıcı bir etki bırakmaması,

e) Deney sırasında kişiye insan onuruyla bağdaşmayacak ölçüde acı verici yöntemlerin uygulanmaması, f) Deneyle varılmak istenen amacın, bunun kişiye yüklediği külfete ve kişinin sağlığı üzerindeki tehlikeye göre daha ağır basması,

g) Deneyin mahiyet ve sonuçları hakkında yeterli bilgilendirmeye dayalı olarak açıklanan rızanın yazılı olması ve herhangi bir menfaat teminine bağlı bulunmaması, gerekir.

(3) (Değişik fikra: 31/03/2005 - 5328 S.K./7.mad) Çocuklar üzerinde bilimsel deneyin ceza sorumluluğunu gerektirmemesi için ikinci fikrada aranan koşulların yanı sıra;

a) Yapılan deneyler sonucunda ulaşılan bilimsel verilerin, varılmak istenen hedefe ulaşmak açısından bunların çocuklar üzerinde de yapılmasını gerekli k1lması,

b) Rıza açıklama yeteneğine sahip çocuğun kendi rızasının yanı sıra ana ve babasının veya vasisinin yazılı muvafakatinin de alınması,

c) Deneyle ilgili izin verecek yetkili kurullarda çocuk sağlığı ve hastalıkları uzmanının bulunması, gerekir...

\section{SONUC}

İnsanlık tarihi ne yazık ki güçlü olanın zayıf olana zarar verdiği örneklerle doludur; ancak makalemizde çeşitli örneklerini verdiğimiz gayrimeşru tıbbi araştırmalar yakın tarihlerde gerçekleşmiştir. Tuskegee ve Guetamala deneylerinin üzerinden yalnızca 50-60 yıl geçmiştir. Bu gibi araştırmalar genelgeçer tıp etiği paradigmasındaki temel ahlaki ilkelere aykırıdır, örneğin önce zarar verme. Geçmişten pişmanlık olarak yorumlanabilecek bir biçimde Bill Clinton ve Barack Obama gibi son dönem Amerikan başkanları bu çalışmalardan ötürü kitlelerden özür dilmiş olsalar da, bugün bu tür deneylerin tekrar gerçekleşmeyeceğinden -ve hatta bir yerlerde gerçekleşmediğinden- emin değiliz. Bu kuşkular nedeniyle düzenleyici-denetleyici nitelikte ve uluslararası geçerlilikte etikolegal mev- 
zuata gereksinim duyulmaktadır (26). Yanı sıra yasal (ve etik) boşluklar oluşmaması için bu metinler çağın gereklerine ve bilimdeki gelişmelere paralel olarak sıklıkla revize edilmektedir. Bu hem bir adaptasyon hem de bir önlem alma çabasıdır; insan (ve hayvan) deneklerin kötü muamele görmesini, acı çekmesini ve sömürülmesini önlemeye yöneliktir. Günümüzde özellikle kök hücre, genetik vb. alanlarda oldukça karmaşı ve teknolojik bilimsel araştırmalar gerçekleştirilmektedir. Dolayısıyla işlem ve yöntem bakımından görece yeni nitelikteki bu gibi araştırmalara paralel olarak, bu deneylerde yaşanabilecek ahlaki-hukuki ihlallerin önlenişine katkıda bulunacak yeni, dinamik etik kodların oluşturulması ve bunların samimiyetle benimsenmesi gerekmektedir.

\section{KAYNAKLAR}

1. Prioreschi P. A History of Medicine: Byzantine and Islamic Medicine. ABD: Horatius Press; 2001:205-10.

2. Riley NS. The legacy of Nazi medicine. The New Atlantis. 2004;5:54-60.

3. The Nuremberg Code; 1947. [İnternet: The National Institutes of Health]. Erişim: https://history.nih.gov/research/downloads/nuremberg.pdf

4. The World Medical Association. The Declaration of Helsinki; 2013. [İnternet: Türk Tabipleri Birliği] Erişim: http:// www.ttb.org.tr/images/stories/file/2013/helsinki.pdf

5. The United Nations. International Covenant on Civil and Political Rights; 1966. [ İnternet: Türkiye Büyük Millet Meclisi] Erişim: http://www2.tbmm.gov.tr/d22/1/10589.pdf

6. The World Psychiatric Association. The declaration of Hawaii. J Med Ethics. 1978;4:71-3.

7. Dommel FW, Alexander D. The Convention on Human Rights and Biomedicine of the Council of Europe. Kennedy Inst Ethic J. 1997;7(3):259-76.

8. Katoğlu T. Türk hukukunun bir parçası olarak Avrupa Konseyi İnsan Hakları ve Biyotıp Sözleşmesi. Ankara Üniversitesi Hukuk Fakültesi Derg. 2006;55(1):157-93.

9. The Council of Europe. The Convention for the Protection of Human Rights and Dignity of the Human Being with regard to the Application of Biology and Medicine: Convention on Human Rights and Biomedicine; 1997. [İnternet: Türkiye Büyük Millet Meclisi] Erişim: https:// www.tbmm.gov.tr/kanunlar/k5013.html

10. The United Nations Educational, Scientific and Cultural Organization (UNESCO). The Universal Declaration on the Human Genome and Human Rights; 1997. [İnternet: UNESCO]. Erişim: http://unesco.org/new/filead-
min/MULTIMEDIA/HQ/SHS/pdf/GENOME-HUMAIN_Turc.pdf

11. The National Commission for the Protection of Human Subjects of Biomedical and Behavioral Research. The Belmont Report; 1979. [İnternet: The National Institutes of Health]. Erişim: https://videocast.nih.gov/pdf/ohrp_ belmont_report.pdf

12. The Council for International Organizations of Medical Sciences (CIOMS). The International Ethical Guidelines for Biomedical Research Involving Human Subjects; 1993, rev. 2002. [İnternet: CIOMS]. Erişim: http://www. cioms.ch/publications/layout_guide2002.pdf

13. Türk Tabipleri Birliği. Tibbi Deontoloji Nizamnamesi 1960. [İnternet: T.C. Resmi Gazete]. Erişim: http://www. resmigazete.gov.tr/arsiv/10436.pdf

14. T.C. Sağlık Bakanlığı. İlaç Araştırmaları Hakkında Yönetmelik; 1993. [İnternet: T.C. Resmi Gazete]. Erişim: http://www.resmigazete.gov.tr/arsiv/21480.pdf

15. T.C. Sağlık Bakanlığı. Farmasötik Müstahzarların Biyoyararlanım ve Biyoeşdeğerliğinin Değerlendirilmesi Hakkında Yönetmelik; 1994. [İnternet: T.C. Resmi Gazete]. Erişim: http://www.resmigazete.gov.tr/arsiv/21942. pdf

16. T.C. Sağlık Bakanlığı. 29.12.1995 tarih ve 51748 sayılı genelge, İyi Klinik Uygulamaları Kılavuzu, İyi Laboratuvar Uygulamaları Kılavuzu; 1995. [İnternet: Türk Farmakoloji Derneği]. Erişim: http://www.tfd.org.tr/eski/klinikarastirma/iku_1995.pdf

17. T.C. Sağlık Bakanlığı. İyi Klinik Uygulamaları Kılavuzu; 1995, rev. 2009, 5/2010, 12/2010, 8/2011, 12/2011, 2013, 2014, 2015. [İnternet: Türkiye İlaç Ve Tibbi Cihaz Kurumu]. Erişim: http://www.titck.gov.tr/PortalAdmin/Uploads/UnitPages/\%C4\%B0yi\%20Klinik\%20 Uygulamalar\%C4\%B1\%20K\%C4\%B1lavuzu.pdf

18. T.C. Sağlık Bakanlığı. Hasta Hakları Yönetmeliği; 1998. [İnternet: T.C. Resmi Gazete]. Erişim: http://www.resmigazete.gov.tr/arsiv/23420.pdf

19. T.C. Sağlık Bakanlığı. Klinik Araştırmalar Hakkında Yönetmelik; 2008. [İnternet: T.C. Resmi Gazete]. Erişim: http://www.resmigazete.gov.tr/eskiler/2008/12/20081023-2.htm

20. T.C. Sağlık Bakanlığı. Klinik Araştırmalar Hakkında Yönetmelik; 2011. [İnternet: T.C. Resmi Gazete]. Erişim: http://www.resmigazete.gov.tr/eskiler/2011/08/20110819-9.htm

21. T.C. Sağlık Bakanlığı. Klinik Araştırmalar Hakkında Yönetmelik; 2013. [İnternet: T.C. Resmi Gazete]. Erişim: http://www.resmigazete.gov.tr/eskiler/2013/04/20130413-7.htm

22. T.C. Sağlık Bakanlı̆̆ı. İlaç ve Biyolojik Ürünlerin Klinik Araştırmaları Hakkında Yönetmelik; 2014. [İnternet: T.C. Resmi Gazete]. Erişim: http://www.resmigazete.gov. tr/eskiler/2014/06/20140625-3.htm 
23. Metin S. Biyo-Tıp Etiği ve Hukuk, 1. ed. İstanbul: On İki Levha Yayıncilı; 2010:402-3.

24. Türkiye Büyük Millet Meclisi. Türkiye Cumhuriyeti Anayasas1; 1982. [İnternet: Türkiye Büyük Millet Meclisi]. Erişim: https://www.tbmm.gov.tr/anayasa/anayasa_2016.pdf

25. Türkiye Büyük Millet Meclisi. Türk Ceza Kanunu; kab. 2004, yür. 2005. [İnternet: T.C. Adalet Bakanlığı]. Erişim: http://www.ceza-bb.adalet.gov.tr/mevzuat/5237.htm

26. Ertin H. Gen teknolojisi ile ilgili etik bildirgeler ve yasal düzenlemeler [doktora tezi]. İstanbul: İstanbul Üniversitesi İstanbul Tip Fakültesi Tip Tarihi ve Etik Anabilim Dalı; 2003. 